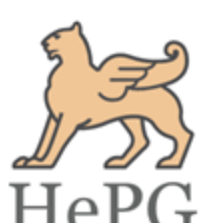

ISSN: 2348-1900

Plant Science Today

http://www.plantsciencetoday.online

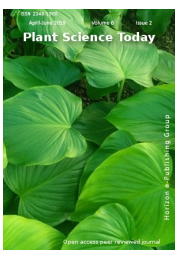

OPEN ACCESS

Research Communication

\title{
Chemical composition of Hedychium coronarium Koen. flowers from eastern India
}

\author{
Reena Parida* \& Sanghamitra Nayak \\ Centre for Biotechnology, Siksha 'O’ Anusandhan University, Kalinga Nagar, Ghatikia, Bhubaneswar- 751 003, Odisha, India
}

\section{Article history}

Received: 18 April 2019

Accepted: 21 May 2019

Published: 02 June 2019

\section{Publisher}

Horizon e-Publishing Group

\section{*Correspondence}

Reena Parida

凶ms.reenas@gmail.com

\begin{abstract}
In this study essential oil from both conventional and micropropagated flowers of Hedychium coronarium were extracted through hydro-distillation process and its chemical composition were analyzed by gas chromatography and mass spectrometry. A total of 11 compounds were identified from conventionally grown plants where as 7 compounds were identified in micropropagated plants. The major compound identified in conventional and micropropagated plantlets is eucalyptol $(18.04 \%$ and $26.47 \%$ ) respectively. The medicinally beneficial compounds present in the oil confirm the plant to be curative for various diseases in human and valuable for commercial purposes.
\end{abstract}

Keywords: Essential oil; medicinal; Gas chromatography-mass spectrometry; eucalyptol.

Citation: Parida R, Nayak S. Chemical composition of Hedychium coronarium Koen. flowers
from eastern India. Plant Science Today 2019;6(2):259-263. https://doi.org/10.14719/pst.2019.6.2.556

Copyright: (C) Parida \& Nayak (2019). This is an open-access article distributed under the terms of the Creative Commons Attribution License, which permits unrestricted use, distribution, and reproduction in any medium, provided the original author and source are credited (https://creativecommons.org/licenses/by/4.0/).

Indexing: Plant Science Today is covered by Scopus,Web of Science, BIOSIS Previews, ESCI, CAS, AGRIS, CABI, Google Scholar, etc. Full list at http://www.plantsciencetoday.online

\section{Introduction}

Hedychium coronarium Koen. (Ginger lily) is well known for its elegant appearance, appealing scent that provides essential oil, flavour to food and perfume industries. The plant is native to the Eastern Himalayan region of India, also is found in China, Japan and Brazil but very little is known about the regulation of the volatile compound biosynthesis (1). This rhizomatous herb is commonly used for eye infections, rheumatism problems and also having wide applications in anthelmintic and mild tranquilizer properties in India (2). Flowers are large white butterfly-shaped formed at the stem tips and lasts only one day. $H$. coronarium is a strong aromatic perennial plant mainly grows in wild up to 3 metres height from a thick fleshy rhizome in moist soil. The plant is valued for its high quality essential oil having various medicinal uses for which sometimes it is cultivated as a crop. It is widely cultivated as an ornamental plant in tropical and subtropical areas of the world. It is also the national plant of Cuba. An essential oil obtained from the flowers is valued in high grade perfumes and plant essential oils are also used medicinally for severe pain during headache, inflammatory and other nerve related problems (3). Its stem contains 43 - 48\% cellulose which is useful in making of paper. Eucalyptol and $\beta$-trans-ocimenone are the major component present in its rhizome and flower 
essential oil having high medicinal value. Eucalyptolis a monoterpenoid used for flavouring and is also medicinal at very low doses. It is an active ingredient in mouthwash preparation, cough suppressant by anti-inflammatory cytokine inhibition and treatment of asthma. Caryophyllene is a natural sesquiterpene having anti-inflammatory properties as well as used in food as preservatives, in preparation of drugs and cosmetics. Alpha-phellandrene is one pair of phellandrene, a monoterpene which acts as an antimicrobial agent and used in fragrances due to its aroma. The cost of its rhizome is 10 dollar, extract of rhizome is 83.5 dollar per $\mathrm{kg}$, oil of rhizome is 59 dollar per $100 \mathrm{ml}$, oil of flower is 12 dollar per $\mathrm{ml}$ and coronarin D is 290 dollar per $5 \mathrm{mg}$ (4). Complete uprooting of plants for medicinal uses and increased market demand of extract, essential oil and Ark (juice) extracted from its white fragrant flowers has made it a critically endangered species in India. The conventional method of propagation through rhizome is very difficult due to over exploitation by humans to fulfill commercial demand and therapeutic uses (5,6). Besides, slow multiplication in wild and heavy collection has decreased the availability of the plants. The enhancement of plant secondary metabolites has important role in biosynthesis pathways to enhance production of commercially important compounds $(7,8)$. These compounds are released due to defense responses in plant tissue culture systems. The tribals still largely depends on local herbal healer and indigenous flora, notwithstanding the spread of modern medicines. Besides its vast medicinal importance very few reports are available on its essential oil composition. Till date there is no data on in-vitro flower oil analysis where major compounds were found in higher percentage in micropropagated plants with comparison to the conventional $H$. coronarium plantlets.

\section{Materials and Methods}

\section{Plant sample collection and Gas chromatography - mass spectrometry}

The plant and rhizome along with its floral parts in the early morning was collected from the wild areas of Eastern Ghats (Phulbani, 20 $28^{\prime} \mathrm{N}$, $\left.84^{\circ} 14^{\prime} \mathrm{E}\right)$. The flowers should be harvested in the morning after the dew has dried when temperatures are low and the plant water content is high. The plant was identified by Dr. P.C. Panda, Principal Scientist (Taxonomy and Conservation Division, Regional Plant Resource Center, Bhubaneswar, India). Then those were maintained in the medicinal plant garden of Centre for Biotechnology, Siksha 'O' Anusandhan University, Bhubaneswar for further study. The bud explant from rhizome of disease-free plants was washed in tap water with a neutral liquid detergent (Extran,
Merck) for five minutes. These explants were sterilized with $0.1 \%$ mercuric chloride for seven minutes in a laminar flow cabinet and rinsed four times in double distilled sterile water for removing sterilants before inoculation. Those buds were inoculated on Murashige and Skoog (MS) medium supplemented with various combination of hormones like benzyl adenine (BA), kinetin (Kin), indole- 3-acetic acid (IAA) and naphthalene acetic acid (NAA) with sucrose $30 \mathrm{gm} / \mathrm{l}$ and agar $0.8 \%$ following our earlier reports $(9,10)$. In-vitro raised plants with shoots and roots were transferred outside for growth and oil extraction from the flowers of matured plants. For conventional plant oil analysis, extraction was done from the mother plants collected from the wild. The flowers of micropropagated plants were freshly collected of about 100gm in early morning and washed in fresh tap water for immediate use in essential oil extraction at the age of two and a half year of the plant. $H$. coronarium flower oil was extracted by hydro-distillation using Clevenger's apparatus following the standard protocol (11). A round bottom flask containing $100 \mathrm{gm}$ of sliced flowers with $500 \mathrm{ml}$ of distilled water was heated for six hours for separation of oil in water surface present in the collection chambers. This transparent oil present at the upper layer were collected in a sterilised Eppendorf tube and kept at $4^{\circ} \mathrm{C}$ for further analysis. To perform GC-MS analysis, $0.1 \mu \mathrm{l}$ of neat oil was injected into the chromatogram system. The identification of the compounds was done by GC-MS analysis using HP 6890 series GC (Hewlett-Packard, USA) coupled with mass selective detector (MSD) HP 5973 series (HewlettPackard). Helium gas was the carrier gas and samples were injected in split less mode in a column HP5. Phenyl methyl siloxane $(25 \mu \mathrm{l}$ film thickness $\times 320 \mu \mathrm{m}$ internal diameter $\times 30 \mathrm{~m}$ length of the column). Mass spectra were acquired over a 40-400 atomic mass unit range. The analysed compounds were identified by comparing its mass spectral data with NIST library. The programming temperature was initially set as $60^{\circ} \mathrm{C}$, ramping rate as $3^{\circ} \mathrm{C}$ and finally as $243^{\circ} \mathrm{C}$ with run time for 61 min. Further the identification of these compounds was assigned on the basis of comparison of their retention indices and mass spectra with those given in the literature (12).

\section{Results and Discussion}

The essential oil extracted was transparent in colour for micropropagated plantlets as $0.28 \%$ and pale yellow colour in conventional plants as $0.15 \%$ respectively. The major compound present in both the oils was eucalyptol which is highly medicinal. The conventional flower oil compounds present were alpha phellandrene, eucalyptol, alpha pinene, beta pinene, linalyl acetate, alpha terpineol, caryophyllene, linalool, caryophyllene oxide, eugenol and alloaromadendrene oxide whereas in micropropagated flower oil, 
Table 1: Chemical composition of flower oil in conventional (CL) and micropropagated (MP) Hedychium coronarium

\begin{tabular}{clcccc}
\hline Sr. No. & Compound name & $\begin{array}{c}\text { Retention } \\
\text { Index (RI) }\end{array}$ & $\begin{array}{c}\text { Molecular } \\
\text { formula }\end{array}$ & $\begin{array}{c}\text { Area \% } \\
\text { (CL) }\end{array}$ & $\begin{array}{c}\text { Area \% } \\
\text { (MP) }\end{array}$ \\
\hline 1 & Alpha phellandrene & 1001 & $\mathrm{C}_{10} \mathrm{H}_{16}$ & 9.78 & 16.67 \\
\hline 2 & Eucalyptol & 991 & $\mathrm{C}_{10} \mathrm{H}_{18} \mathrm{O}$ & 18.04 & 26.47 \\
\hline 3 & Alpha pinene & 929 & $\mathrm{C}_{10} \mathrm{H}_{16}$ & 8.21 & - \\
\hline 4 & Beta pinene & 979 & $\mathrm{C}_{10} \mathrm{H}_{16}$ & 15.13 & - \\
\hline 5 & Linalyl acetate & 1051 & $\mathrm{C}_{12} \mathrm{H}_{20} \mathrm{O}_{2}$ & 9.26 & 10.06 \\
\hline 6 & Alpha terpineol & 1178 & $\mathrm{C}_{10} \mathrm{H}_{18} \mathrm{O}$ & 6.01 & 8.66 \\
\hline 7 & Caryophyllene & 1417 & $\mathrm{C}_{15} \mathrm{H}_{24}$ & 10.15 & 19.98 \\
\hline 8 & Linalool & 1090 & $\mathrm{C}_{10} \mathrm{H}_{18} \mathrm{O}$ & 5.30 & - \\
\hline 9 & Caryophyllene oxide & 1568 & $\mathrm{C}_{15} \mathrm{H}_{24} \mathrm{O}$ & 7.08 & 10.11 \\
\hline 10 & Eugenol & 1345 & $\mathrm{C}_{10} \mathrm{H}_{12} \mathrm{O}_{2}$ & 3.09 & - \\
\hline 11 & Alloaromadendrene oxide & 1631 & $\mathrm{C}_{15} \mathrm{H}_{24} \mathrm{O}$ & 5.91 & \\
\hline
\end{tabular}

compounds were alpha phellandrene, eucalyptol, linalyl acetate, alpha terpineol, caryophyllene, caryophyllene oxide and alloaromadendrene oxide. In case of conventional and micropropagated flower oils, there were eleven and seven constituents representing $97.96 \%$ and $99.99 \%$ of the oil were identified (Table 1, Fig. 1). The GC-MS chromatogram of both the oils have been shown (Fig. $2 \mathrm{a}, \mathrm{b}$ ). There are reports on the chemical composition of flower essential oil in $H$. coronarium along with its anti-inflammatory activity (13). Their GC-MS showed 29 compounds, major compound present was trans-ocimenone (28.05\%), linalool (18.52\%) and 1, 8-cineole $(11.35 \%)$ respectively. The relative percentage of each was calculated by comparing its average peak area with the total area present. Studies on $H$. coronarium rhizome and flower oil composition and isolation of several diterpenes and sesquiterpenes has been done (14-16). Others studies on GC-MS analysis and antimicrobial activity of $H$. coronarium oils has been reported (17-21). In their reports the dominant component of the oils were monoterpenes and sesquiterpenes, especially 1, 8-cineole (42\%), linalool (56\%), alphapinene $(17 \%)$ and beta-pinene (31\%) similarly in the present study eucalyptol is present in higher percentages. Pharmacological studies have also been reported in which analgesic and antiinflammatory activities of $H$. coronarium were studied in animal model (22). The phytochemical constituents and total phenolic content study of three different species extracts of Hedychium including $H$. coronarium has been reported (23). In their study methanolic extracts used in each species showed a moderate quantity of phenolic compounds which might exhibit antioxidant activity. Also there are reports on the use of flowers of $H$. coronarium as flavoured tea (24). Though terpenes were identified in both samples but composition pattern was different in same species might be for other factors as previously studied by researchers (25). The quantitative composition and the relative proportions of oil are widely influenced by various factors such as nature, age, plant genotype, environment, growth conditions, experimental procedures etc. It might be responsible for the observed variations between the present study and published reports of conventional plants. At the same time these micropropagated $H$. coronarium plants could be conserved in-vitro for commercial purposes.

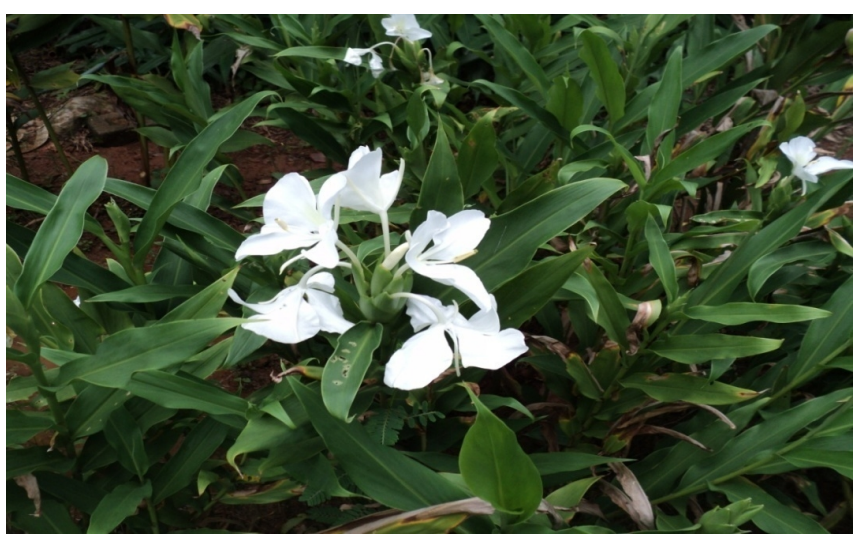

Fig. 1. Field grown in-vitro flowers of Hedychium coronarium

\section{Conclusion}

The results have shown the chemical composition of in-vitro raised plantlets flower essential oil of $H$. coronarium for the first time. The present study could be useful for conservation purposes for making the plant available throughout the year by tissue culture method for obtaining valuable secondary metabolites. It can be illustrated that difference in major oil content might be due to difference in circumstances i.e. age, pressure, temperature and soil composition which could be further studied. The GC shows the relative concentrations of the compounds and the MS analyzes their nature and structure. The heights of the peak indicate the comparative concentrations of the components present in the samples. Those mass spectra are fingerprint of the present compounds in the sample identified from the library which could further help as a tool for identification of the plant. Hence the GC-MS profile may be used for identification of the plant and provide foundation for future studies on the 


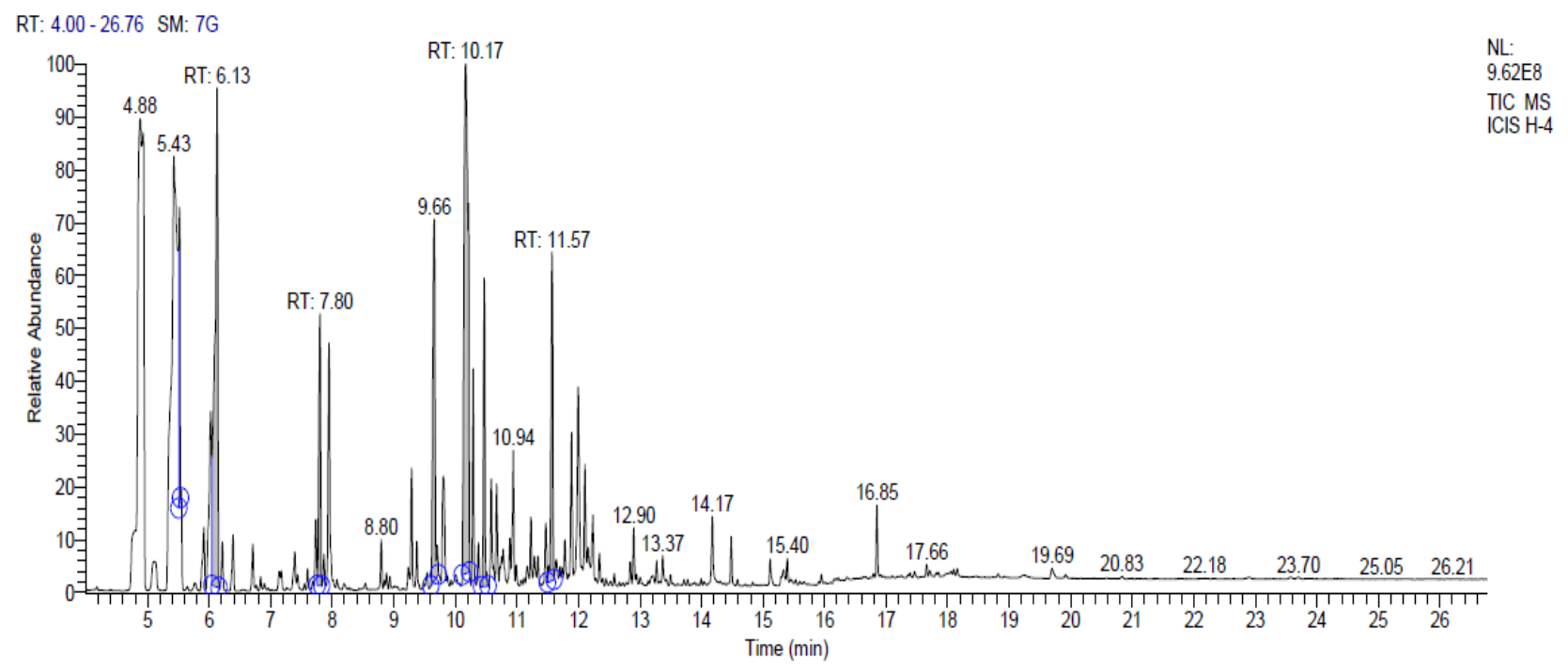

Fig. 2. (a) Gas chromatography-mass spectrometry chromatogram of conventional Hedychium coronarium

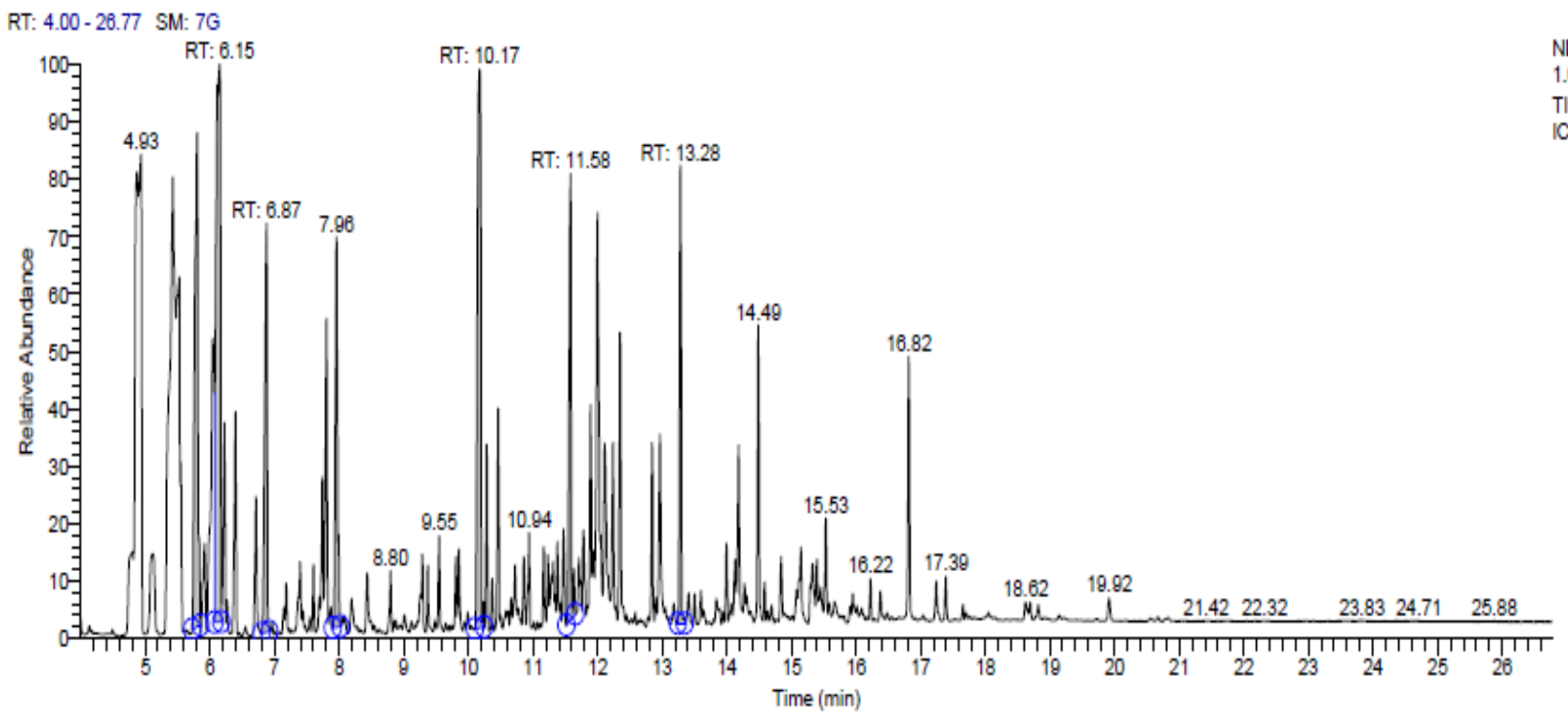

Fig. 2. (b) Gas chromatography-mass spectrometry chromatogram of micropropagated Hedychium coronarium

molecular mechanism involved in floral scent production.

\section{Acknowledgements}

The authors would like to thank Prof (Dr.) Manoj Ranjan Nayak, President and Dr. S. C. Si, Dean of Centre for Biotechnology of Siksha 'O' Anusandhan University for providing facilities and encouragement throughout. The financial support was given by Science and Engineering Research Board in the form of Start-Up Research Grant for Young Scientists (Ref. No. SB/YS/LS-33/2014).

\section{Author's contribution}

All authors contributed equally to carry out the research work.

\section{Competing Interest}

The authors have declared that there are no competing interests.

\section{References}

1. Branney TME. Hardy gingers including Hedychium, Roscoea and Zingiber. Portland, OR: Timber Press Inc. 2005.

2. Jain SK, Prakash V. Zingiberaceae in India: Phytogeography and Endemism. Rheedea 1995;5:154169.

3. Bhandari MJ, Chandrasekhar KR, Kaveriappa KM. Medical ethnobotany of the Siddis of Uttar Kannada district, Karnataka, India. J acol. 1995;47:149-158. https://doi.org/10.1016/0378-8741(95)01274-H

4. Parida R. Coronarin D production from tissue cultured plantlets of Hedychium coronarium. Journal of Biologically Active Products from Nature 2018;8(3):162170. https://doi.org/10.1080/22311866.2018.1476181 
5. Chadha S. Vulnerable and threatened plants of economic value. Hedychium coronarium Koen. MFP News 2005:15.

6. Manish M. Current status of endangered Medicinal plant Hedychium coronarium and causes of Population decline in the natural forests of Anuppur and Dindori districts of Madhya Pradesh, India. Int Res J Biol Sci. 2013;2:1-6.

7. Patel H, Krishnamurthy R. Elicitors in plant tissue culture. J Pharmacogn Phytochem. 2013;2:60-65.

8. Manjula R, Mythili T. Improved phytochemical production using biotic and abiotic elicitors in Marsilea quadrifolia. Int J Curr Sci. 2012:98-101.

9. Murashige T, Skoog F. A revised medium for rapid growth and bioassays with tobacco tissue culture. Physiol Plant. 1962;15:473-479. https://doi.org/10.1111/j.1399-3054.1962.tb08052.x

10. Parida R, Mohanty S, Nayak, S. In vitro propagation of Hedychium coronarium Koen. through axillary bud proliferation. Plant Biosys. 2013;4:905-912. https://doi.org/10.1080/11263504.2012.748102

11. Guenther E. The production of essential oils. In: Robert E (ed) The essential oils, vol I. Krieger, New York 1972: 361-391.

12. Adams R. Identification of essential oil components by gas chromatograph/mass spectrometry. 4th ed. Allured Publishing Corpoartion, Carol Stream, USA. 2007.

13. Lu Y, Zhong CX, Wang L, Lu C, Li XL, Wang PJ. Antiinflammation activity and chemical composition of flower essential oil from Hedychium coronarium. Afr J Biotechnol. 2009;8:5373-5377.

14. Matsuda H, Morikawa T, Sakamoto Y, Toguchida I, Yoshikawa M. Labdane-type diterpenes with inhibitory effects on increase in vascular permeability and nitric oxide production from Hedychium coronarium. Bioorg Med Chem. 2002;10:2527-2534. https://doi.org/10.1016/S0968-0896(02)00121-9

15. Morikawa T, Matsuda $\mathrm{H}$, Sakamoto $\mathrm{Y}$, Ueda $\mathrm{K}$, Yoshikawa M. New franesane type sesquiterpenes,hedychiols $\mathrm{a}$ and $\mathrm{b}$ 8,9- diacetate and inhibitors of degranulation in rbl-2h3 cells from the rhizome of Hedychium coronarium. Chem Pharm Bull (Tokyo). https://doi.org/10.1248/cpb.50.1045 2002;8:1045-1049.

16. Shrotriya S, Ali MS, Saha A, Bachar SC, Islam MS. Antiinflammatory and analgesic effects of Hedychium coronarium Koen. Pak J Pharm Sci. 2007;20:47-51.
17. Schmidt E, Jirovetz L, Buchbauer G, Denkova Z Stoyanova A, Murgov I, Geissler M. Antimicrobial testings and gas chromatographic analyses of aroma chemicals. J Essent. Oil Bearing Plant. 2005;8:99-106. https://doi.org/10.1080/0972060X.2005.10643427

18. Joy B, Rajan A, Abraham, E. Antimicrobial activity and chemical composition of essential oil from Hedychium coronarium. Phytother Res. 2007;21:439-443. https://doi.org/10.1002/ptr.2091

19. Bruna S, Lauro B, Francisco M, Adriano B, Bruno K, Paulo O, Palimecio G. Composition of leaf and rhizome essential oils of Hedychium coronarium Koen. from Brazil. J Essent Oil Res. 2010;4:305-306 https://doi.org/10.1080/10412905.2010.9700331

20. Sakhanokho HF, Sampson BJ, Tabanca N, Wedge DE, Demirci B, CanBaser KH, Bernier UR, Tsikolia M, Natasha MA, Becnel JJ, Chen J, Rajasekaran K, James MS. Chemical composition, antifungal and insecticidal activities of Hedychium essential oils. Molecules 2013;18:4308-4327. https://doi.org/10.3390/molecules18044308

21. Zhao C, Gong X, Chen H, Yang Z, Zhou X. Analysis of volatile oil in Hedychium coronarium from Guizhou by SPME/GC/MS. China. J Trad Chin Med Pharm. 2010;7:3439.

22. Seikou N, Yoshie O, Kiyofumi N, Toshio M, Hisashi M, Masayuki Y. Medicinal flowers chemical structures and hepatoprotective effects of constituents from flowers of Hedychium coronarium. Chem Pharm Bull. 2008;56:1704-1709. https://doi.org/10.1248/cpb.56.1704

23. Singh KL, Singh LR, Devi PG, Devi NR, Singh LS, Bag GC. Comparative study of phytochemical constituents and total phenolic content in the extracts of three different species of genus Hedychium. Int J Pharm Tech Res. 2013;5:601-606.

24. Suksathan R, Puangpradap R, Saratan N, Boonvun D. Bioactive compounds and antioxidant properties of four Hedychium flowers for flavoured tea. Acta Hortic. 2018;1194:1053-1056. https://doi.org/10.17660/ActaHortic.2018.1194.150

25. Lamya FA, Wafaa ME, Mariam HG, Kamel AE. Difference in chemical composition and antimicrobial activity of Thymus capitatus L. essential oil at different altitudes. Future J Pharma Sci. 2018;4:156-160. https://doi.org/10.1016/ j.fjps.2017.12.004 